Short Communication

\title{
Analysis of the expression of platelet antigens CD9 and CD41/61 in transgenic rabbits with the integrated human blood clotting factor VIII gene construct
}

\author{
Michal Simon ${ }^{1}$, Jana Antalikova ${ }^{1}$, Peter Chrenek ${ }^{2,3}$, Lubica Horovska1, Svatoslav Hluchy², Katarina \\ Michalkova ${ }^{1}$, Jana Jankovicova ${ }^{1}$ and Vladimir Tancin ${ }^{3}$ \\ ${ }^{1}$ Institute of Animal Biochemistry and Genetics, Centre of Excellence of Slovak Research and Development Agency „Bio- \\ membranes 2008", Slovak Academy of Sciences, Ivanka pri Dunaji, Slovak Republic \\ 2 Slovak University of Agriculture, Nitra, Slovak Republic \\ ${ }^{3}$ Animal Production Research Centre Nitra, Centre of Excellence of Slovak Research and Development Agency „Biomem- \\ branes 2008“, Slovak Republic
}

\begin{abstract}
The objective of this research was to study the expression of cell membrane molecules CD9 and CD41/61 of transgenic rabbit with integrated human factor VIII (rhFVIII) gene construct. The expressions of these molecules have been monitored during two lactations of transgenic rabbits and simultaneously compared with the expression of the same molecules of non-transgenic rabbits. The immunochemical analysis by indirect immunofluorescence, ELISA and indirect immunoperoxidase staining of blood cells and udder tissues show that the insertion of the WAP-hFVIII gene construct into the rabbit genome, do not influence the expression of cell membrane antigens CD9 and CD41/61 on the blood platelets, polymorphonuclear blood cells, milk somatic cells and mammary gland tissues.
\end{abstract}

Key words: Transgenic animals - CD molecules — Factor VIII — Rabbits

The transgenic technology offers a great possibility for generating the animal models for human genetic diseases and for producing of economically important proteins by means of genetically engineered farm animals. Transgenic rabbits have recently been found to be suitable bioreactors for the production of pharmaceutical proteins and an excellent animal model for inherited and acquired human diseases (reviewed by Bösze et al. 2003). The rabbit mammary gland has been successfully employed for the production of the pharmaceutically attractive human blood clotting factor VIII, using the transgenic rabbits with integrated mammary gland specific human factor VIII (hFVIII) gene construct. Biologically active hFVIII was obtained from the transgenic rabbits prepared by introducing of gene construct into the pronuclei of rabbit zygotes (embryos)

Correspondence to: Jana Antalikova, Institute of Animal Biochemistry and Genetics, Slovak Academy of Sciences, Moyzesova 61, 90028 Ivanka pri Dunaji, Slovak Republic

E-mail: Jana.Antalikova@savba.sk
(Hiripi et al. 2003; Chrenek et al. 2005). The specificity of recombinant hFVIII (rhFVIII) as well as the physiological, morphological and production characters of transgenic animals produced by Chrenek and co-workers have been studied. There were no differences in the essential physiological functions of transgenic and untreated animals. However, significant differences have been noted in some parameters of spermatozoa quality (Chrenek et al. 2007). The morphometrical analysis of histological preparations of mammary gland and the milk composition analysis have revealed the differences in histological structure, the percentage of apoptic cells and in the content of milk protein (Chrenek et al. 2009).

The blood coagulation (clotting) is a complex cascade process in which a set of blood factors are comprises. The coagulation involves both a cellular (platelets) and protein (coagulation factors) components. The factor VIII is activated by von Willebrand factor at the beginning of coagulation cascade. Some cell surface molecules (CD antigens) mediate the interaction of thrombocyte and coagulation 
factors. CD41/CD61 (GPIIb-IIIa) is the major integrin on platelets and is important for platelet adhesion and aggregation. The ligands for CD41/CD61 include fibrinogen, von Willebrand factor, fibronectin and thrombospondin (Barclay et al. 1997; Ni and Freedman 2003). The CD9 leukocyte differentiation antigen is also a major component of the platelet membrane. The observation that CD9 and CD41/CD61 are localized in the same intracellular structures and migrate to the same activation zones after platelet stimulation suggested a close association between CD9 and CD41/CD61 in human platelets and of a possible involvement of CD9 in adhesive functions of platelets (Brisson et al. 1997). Furthermore, different authors have shown that most monoclonal antibodies against CD9 induce platelet activation and aggregation (Boucheix et al. 1983b; Griffith et al. 1991).

In the current study, we investigated whether insertion of hFVIII gene construct into rabbit genome could modify the expression of thrombocyte surface molecules CD9 and CD41/CD61, taking part in the process of blood coagulation.

Eight female rabbits of New Zealand breed, maintained in the Animal Production Research Centre Nitra, were used in these experiments. Four of them were transgenic founders with the WAP-hFVIII gene construct described by Chrenek et al. (2005) and four randomly selected untreated rabbits housed in the same conditions served as control animals. The gene construct composed from promoter of mice whey protein (mWAP) and human blood clotting factor VIII, producing the factor VIII into milk during the lactation period. The blood and milk samples have been collected at the 18th, 25th and 32nd day of the first lactation and the 19th and 26th day of the second lactation.

The tissue samples for immunochemistry and blotting from tissue homogenate have been taken after the killing of animals. The milk samples from the lactating rabbits were obtained by a vacuum pump. Ten minutes before the milking 5 IU of oxytocin was applied to each rabbits. The samples were diluted $1: 1$ in solution of PBS and centrifuged at $1500 \times g$ for 30 minutes. The fat from the upper part of tubes were removed and cell pellets of skim milk have been collected, 2 times washed, and resuspended in the medium (PBS with $1.7 \mathrm{mmol} / 1$ sodium citrate, $1.3 \mathrm{mmol} / \mathrm{l}$ citric acid, $2.2 \mathrm{mmol} / \mathrm{l} \mathrm{D}$-glucose, $20 \mathrm{mmol} / \mathrm{l}$ EDTA). Blood samples, collected with drawn blood from ear vein of rabbit into heparin containing flasks (10 IU/ml), were centrifuged via Verografin (SPOFA, Czech Republic) density gradient (Simon et al. 1991) to isolate the different population of blood cells. The purity of isolated cells has been controlled with staining the smears of cells by Pappenheim method.

Hybridoma cell lines producing monoclonal antibodies (mAbs) recognizing the bovine cell surface molecules were obtained after immunisation of BALB/c mice with bovine peripheral blood leukocytes using standard procedures for fusion of SP2/0 with splenocytes of immunised mice, selection and cloning of hybridomas (Kováčiková et al. 2001). In this study, the expression of CD9 and CD41/61 on rabbit cells has been determined by mAbs, being cross-reactive, recognizing the homologue $\mathrm{CD}$ molecules on rabbit blood and milk cells (Simon et al. 2009).

For histochemical studies, series of cryostat 5-10 $\mu \mathrm{m}$ thick tissue sections were prepared from each sample of rabbit udder tissues with Leica cryocut 1800 cryostat. The sections were fixed in cold ethanol-acetone mixture and then processed using indirect immunoperoxidase test ( $\mathrm{Na}$ kane and Pierce 1967). The sections were incubated with the primary antibody, labelled with peroxidase-conjugated pig anti-mouse immunoglobulin (Ig) (Sevac), incubated in diaminobenzidine tetrachloride and contra stained by Harris's hematoxylin.

Indirect immunofluorescence assay described by Boucheix et al. (1983a) was used to test the binding of mAbs to blood leukocytes. The separated cells were incubated with tested monoclonal antibody, and then treated with fluorescein isothiocyanate (FITC)-conjugated swine anti-mouse Ig and the reactions examined under a Leica DM5500 epifluorescence microscope.

ELISA test was performed as previously described (Kennett 1983). The wells in Terasaki microtiter plates were coated with poly-L-lysine and left overnight at $4^{\circ} \mathrm{C}$. To each wells the suspension of blood cells in PBS was added and incubated at laboratory temperature. Than the plates were incubated with PBS containing glutaraldehyd $(20 \mu \mathrm{l} / 10 \mathrm{ml}$ PBS $)$ and the open sites of plate were blocked with $0.1 \%$ gelatine in PBS. The aliquots of mAbs were added to each well and the plates were incubated. Swine anti-mouse secondary antibody conjugated to horseradish peroxidase was used as secondary antibody. The peroxidase activity was detected using $o$-phenylendiamine. Among the "steps" the plates were washed with $0.25 \%$ Tween 20 in $0.9 \% \mathrm{NaCl}$.

The presence of CD molecules in rabbit udder tissue was tested by Western blot in protein extracts. Tissues were solubilised in lysis buffer (25 mmol/1 Tris- $\mathrm{HCl}, \mathrm{pH} 7.4 ; 154$ mmol/1 NaCl; 5 mmol/l EDTA; 1\% NP40; 2 mmol/l PMSF; cocktail of protease inhibitors), separated by SDS-PAGE (non-reduction conditions) (Laemli 1970) transferred on PVDF membrane (Towbin et al.1979) and analysed by immunoblotting with primary mAbs, followed by anti-mouse Ig alkaline phosphatase conjugate (Sigma, USA) and detected using BCIP/NBT.

Student's $t$-test was used to compare the reactions of $\mathrm{mAbs}$ on rabbit and bovine cells in indirect immunofluorescence.

The monoclonal antibodies IVA-50, IVA-31, IVA-38, IVA-125 detecting the cell membrane molecules CD9 
Table 1. Reactions of mAbs with milk somatic cells and blood cells of transgenic and non-transgenic rabbits

\begin{tabular}{|c|c|c|c|c|c|c|c|c|c|c|c|c|c|}
\hline \multirow{3}{*}{$\mathrm{mAb}$} & \multirow{3}{*}{ Specificity } & \multicolumn{4}{|c|}{ Somatic cells (SCC) } & \multicolumn{4}{|c|}{ Blood granulocytes } & \multicolumn{4}{|c|}{ Blood platelets } \\
\hline & & Transgenic & & $\begin{array}{l}\text { Non-trans- } \\
\text { genic }\end{array}$ & & Transgenic & & $\begin{array}{l}\text { Non-trans- } \\
\text { genic }\end{array}$ & & Transgenic & & $\begin{array}{l}\text { Non-trans- } \\
\text { genic }\end{array}$ & \\
\hline & & IF & $\mathrm{E}$ & IF & $\mathrm{E}$ & IF & $\mathrm{E}$ & IF & $\mathrm{E}$ & IF & $\mathrm{E}$ & IF & $\mathrm{E}$ \\
\hline IVA-50 & CD9 & $45.30 \pm 4.73$ & NT & $47.40 \pm 5.71$ & NT & $80.60 \pm 3.80$ & ++ & $80.10 \pm 4.45$ & ++ & $92.20 \pm 4.02$ & +++ & $92.40 \pm 2.98$ & ++ \\
\hline IVA-31 & CD9 & $41.20 \pm 5.18$ & NT & $46.80 \pm 5.39$ & NT & $76.10 \pm 3.95$ & + & $76.30 \pm 4.13$ & + & $82.60 \pm 4.32$ & ++ & $83.00 \pm 4.52$ & + \\
\hline IVA-38 & CD41/61 & $29.30 \pm 3.86$ & NT & $30.70 \pm 2.05$ & NT & $12.50 \pm 3.10$ & +- & $11.40 \pm 2.63$ & + & $92.70 \pm 4.11$ & + & $93.50 \pm 2.91$ & ++ \\
\hline IVA-125 & CD41/61 & $27.15 \pm 3.72$ & NT & $29.94 \pm 2.99$ & NT & $12.80 \pm 4.18$ & + & $13.00 \pm 3.23$ & + & $81.00 \pm 3.262$ & + & $80.00 \pm 3.59$ & + \\
\hline
\end{tabular}

The values are \% mean \pm SD. mAb, monoclonal antibody; IF, indirect immunofluorescence; E, ELISA assay; NT, not tested. Intensity of reaction: +++ intense, ++ moderate, + weak, +- very slight staining of some portion of cells. (The table shows the most frequent reaction).

and CD41/61 have been tested on each sample of control and transgenic rabbit blood cell populations and milk somatic cells. The reactions of four mAbs in indirect immunofluorescence and ELISA tests on the subsets of rabbit leukocytes and milk somatic cells of control animals were compared with reactions on the same cell populations of transgenic rabbit cells. The data (percentage of stained cells) obtained from various stages of the first and second lactation were compared. No significant differences have been shown among measurements during the lactations, therefore in Table 1, the pooled data (five sampling) of the control group and the group of transgenic rabbits is compared. Comparison of the staining pattern and intensity of reaction of the mAbs (immunofluorescence and ELISA) revealed the high concordance of IVA-50 on the cells of both groups. Intensive reactions were observed on the platelets and less intensive staining (lower percentage of stained cells) on the granulocytes and no clear reaction was observed on lymphocytes (data not shown in the Table 1). The reaction pattern of IVA-31 was similar to that of IVA-50 but the staining was less intensive. The expression of CD9 on rabbit leukocytes has demonstrated, as expected from the known distribution of human CD9 (Barclay et al. 1997). The CD41/61 antigen recognized by mAbs IVA-38 and IVA-125 is of a restricted distribution on granulocyte population being expressed mainly on platelets and monocytes/macrophages. The IVA-38 and IVA-125 are equally reactive on rabbit blood cells, on the control and transgenic animals apart from the platelets also with a small population of granulocytes. Since, the WAP-hFVIII gene construct is active in the lactation stage, releasing the hFVIII into the mammary gland secret, it was investigated whether the expression of two thrombocyte CD molecules on transgenic rabbit milk leukocytes was similar to their patterns on control animals. The immunofluorescence analysis of milk somatic cells revealed that approximately
$45 \%$ of milk cells are positive for CD9 and 29\% for CD41/61 while no significant differences were noticed in the relation control and transgenic rabbits. The higher percentage of stained cells with CD9 antibodies is probably due to the reactivity of these antibodies with the major population of granulocytes and macrophages, while the expression of CD41/61 is restricted to the macrophages. The Pappenheim staining has shown that in rabbit milk the predominant cell type were lymphocytes 54\%, macrophages 33\% and polymorphonuclear cells $11 \%$.

To study the expression of CD9 and CD41/61 in rabbit mammary gland tissue the four mAbs were tested simultaneously by immunoblotting and indirect immunoperoxidase staining with tissue samples of both transgenic and non-transgenic animals. Reactions of the mAbs IVA-38, IVA-125 and IVA-31 in immunoblotting were weak and sporadic. Therefore, no appreciable data were obtained from their testing. The Western blot analysis has shown

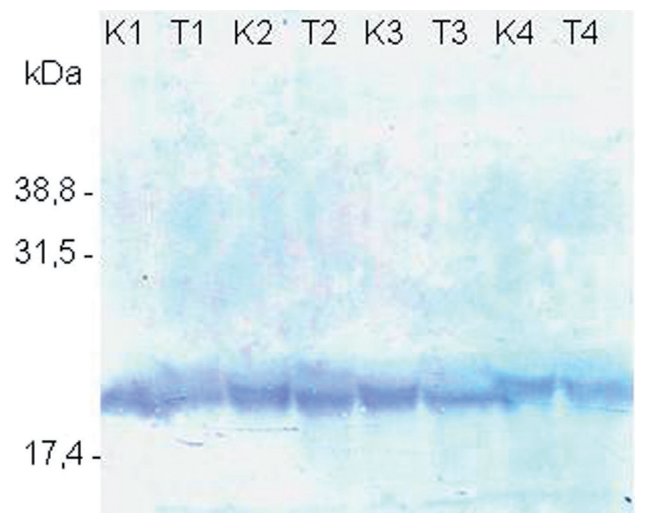

Figure 1. Reactivity of mAb IVA-50 (CD9) with detergent extracts of mammary gland tissues of four transgenic $(\mathrm{T})$ and non-transgenic $(\mathrm{K})$ rabbits. 
that the molecular weight of antigen recognized by IVA50 on rabbit mammary gland is in good agreement with the molecular weight of homologous CD9 molecules. The IVA-50 in all samples (protein extracts) under non-reduction conditions recognized the band with molecular weight $22-24 \mathrm{kDa}$ (Figure 1).

Tissue sections from the same samples as for Western blotting were used in immunoperoxidase assay to test the immunoreactivity of IVA-50 (CD9) and IVA-125 (CD41/61) in transgenic and normal mammary gland tissues. The staining pattern of the cryostat sections of both types of rabbits was very similar no clear differences were identified. High expression of CD9 was found in the epithelial cells of alveoli and in the connective tissue (Figure 2a,b); while the
CD41/CD61 is expressed intensively, only on epithelial cells (Figure 2c,d).

In conclusion, these studies show that the insertion of the WAP-hFVIII gene construct (producing the hFVIII during the lactation) into the rabbit genome does not influence the expression of cell membrane antigens CD9 and CD41/61 on the blood platelets, polymorphonuclear blood cells, milk somatic cells and mammary gland tissues, measured by the applied detection methods (ELISA, indirect immunofluorescence, indirect immunoperoxidase test and immunoblotting). In future, the study could be extended for larger group of animals including the evaluation of $\mathrm{CD}$ molecules expression in relation to the concentration of the rhFVIII in rabbit milk.
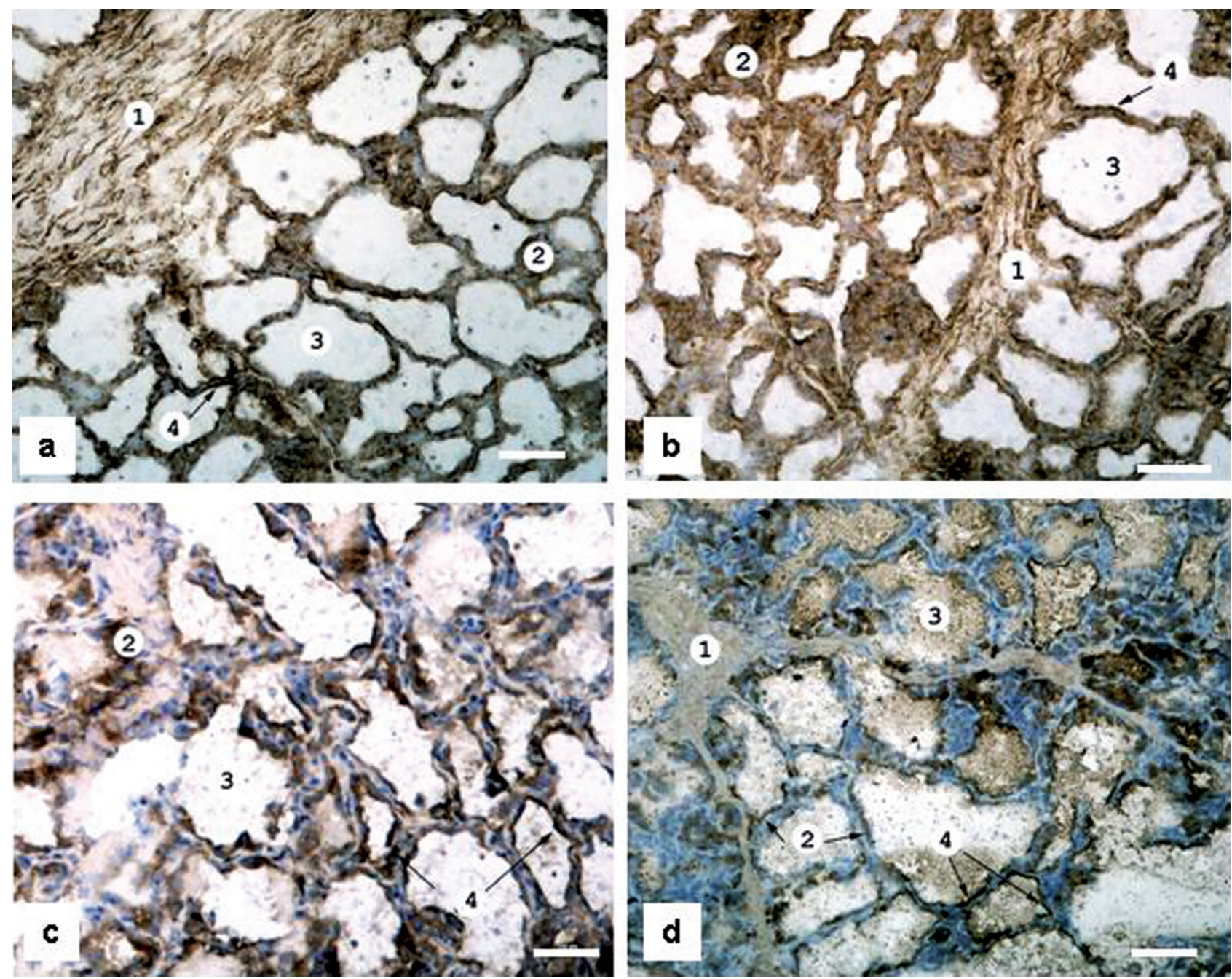

Figure 2. Immunohistochemical staining of rabbit mammary gland sections immunostained with mAbs. a. Non-transgenic rabbit IVA50 (CD9): reaction (staining) in 1, 2, 4. b. Transgenic rabbit IVA-50 (CD9): reaction (staining) in 1, 2, 4. c. Non-transgenic rabbit mAb IVA-125 (CD41/61): reaction (staining) in 4. d. Transgenic rabbit mAb IVA-125 (CD41/61): reaction (staining) in 4. 1, collagenous tissue (separating the lobules of glandular parenchyma from each other); 2, loose connective tissue (fills space between alveoli inside the lobules of glandular parenchyma of mammary gland); 3 , the lumen of alveoli; 4, secretory epithelial cells of alveoli. Scale bar $=100 \mu \mathrm{m}$. 
Acknowledgements. This work was supported by the Scientific Grant Agency of the Ministry of Education of the Slovak Republic, the Slovak Academy of Sciences (VEGA-2/0001/09) and the Slovak Research and Development Agency (APVVVVCE-0064-07). M. S., J. A., P. Ch., L. H., S. H., K. M., J. J. and $\mathrm{V}$. T. have no conflict of interest and no financial interest in the publication of this manuscript.

\section{References}

Barclay A. N., Brown M. H., Law S. K. A., McKnight A. J., Tomlinson M. G., van der Merwe P. A. (1997): A rapid method for detection of membrane antigens by immunofluorescence and its application to screening hybridoma antibodies. In: The Leukocyte Antigen. Facts Book, pp. 152-153, Academic Press, London doi:10.1016/B978-012078185-0/50440-6

Boucheix C., Perrot J. Y., Mirshahi M., Bernadou A., Rosenfeld C. (1983a): A rapid method for detection of membrane antigens by immunofluorescence and its application to screening hybridoma antibodies. J. Immunol. Methods 57, 145-150 doi:10.1016/0022-1759(83)90072-8

Boucheix C., Soria C., Mirshahi M., Soria J., Perot J. Y., Fournier N., Billard M., Rosenfeld C. (1983b): Characteristics of platelet aggregation induced by the monoclonal ALB6 (acute lymphoblastic leukemia antigen p24). Inhibition of aggregation by ALB6Fab. FEBS Lett. 161, 289-293 doi:10.1016/0014-5793(83)

Bősze Z., Hiripi L., Carnwath J. W., Niemann H. (2003): The transgenic rabbit as model for human diseases and as a source of biologically active recombinant proteins. Transgenic Res. 12, 541-553 doi:10.1023/A:1025816809372

Brisson C., Azorsa D. O., Jennings L. K., Moog S., Cazenave J. P., Lanza F. (1997): Co-localization of CD9 and GPIIb-IIIa (alphaIIb beta 3 integrin) on activated platelet pseudopods and alpha-granule membranes. Histochem. J. 29, 153-165 doi:10.1023/A:1026437522882

Chrenek P., Vasicek D., Makarevich A. V., Jurcik R., Suvegova K., Parkanyi V., Bauer M., Rafay J., Batorova A., Paleyanda R. K. (2005): Increased transgene integration efficiency upon microinjection of DNA into both pronuclei of rabbit embryos. Transgenic Res. 14, 417- 428 doi:10.1007/s11248-005-3238-8

Chrenek P., Trandzik J., Massanyi P., Makarevich A. V., Lukac N., Peskovicova D., Paleyanda R. (2007): Effects of transgenesis on reproductive traits of rabbit males. Anim. Reprod. Sci. 99, 127-134 doi:10.1016/j.anireprosci.2006.04.052
Chrenek P., Makarevich A. V., Pivko J., Massanyi P., Lukac N. (2009): Characteristic of rabbit transgenic mammary gland expressing recombinant human factor VIII. Anat. Histol. Embryol. 38, 85-88 doi:10.1111/j.1439-0264.2008.00875.x

Griffith L., Slupsky J., Seehafer J., Boshkov L., Shaw A. R. E. (1991): Platelet activation by immobilized monoclonal antibody: evidence for a CD9 proximal signal. Blood 78, 1753-1759

Hiripi L., Makovics F., Halter R., Baranyi M., Paul D., Carnwath J. W., Bösze Zs., Niemann H. (2003): Expression of active human blood clotting Factor VIII in the mammary gland of transgenic rabbits. DNA Cell Biol. 22, 41-45 doi:10.1089/104454903321112488

Kennett R. H. (1983): Enzyme-linked antibody assay with cells attached to polyvinyl chloride plates. In: Monoclonal antibodies. Hybridomas: a new dimension in biological analysis. (Eds. Kennett R. H., McKern T.J. and Bechtol K.B.), pp. 376-377, Plenum Press, New York

Kováčiková P., Simon M., Dušinský R., Horovská L'. (2001): The monoclonal antibodies against the bovine sperm. Czech J. Anim. Sci. 46, 333-338

Laemli U. K. (1970): Cleavage of structural proteins during the assembly of the head of bacteriophage T4. Nature (London) 227, 680-685 doi: $10.1038 / 227680 \mathrm{a} 0$

Nakane P. K., Pierce G. B. (1967): Enzyme labelled antibodies: preparation and application for the localization of antigens. J. Histochem. Cytochem. 14, 929-931 doi:10.1177/14.12.929

Ni H., Freedman J. (2003): Platelets in hemostasis and thrombosis: role of integrins and their ligands. Transfus. Apher. Sci. 28, 257-264 doi:10.1016/S1473-0502(03)00044-2

Simon M., Hruban V., Dušinský R. (1991): Identification of medullar thymocytes by means of a monoclonal antibody. Funct. Develop. Morphol. 1, 27-29

Simon M., Antalíková J., Horovská L., Jankovičová J., Fábryová K., Hluchý S., Chrenek P., Tančin V. (2009): Analysis of rabbit cell surface $(\mathrm{CD})$ antigens by means of cross-reactive monoclonal antibodies with specificity for cattle CD antigens. Czech J. Anim. Sci. 54, 270-276

Towbin J., Staehelin T., Gordon J. (1979): Electrophoretic transfer of proteins from polyacrylamide gels to nitrocellulose sheets: procedure and some applications. Proc. Nat. Acad. Sci. U.S.A. 76, 4350-4354 doi:10.1073/pnas.76.9.4350

Received: October 11, 2010

Final version accepted: December 20, 2010 